\title{
EDITORIAL OPEN \\ Prognostic gene expression assays in breast cancer: are two better than one?
}

npj Breast Cancer (2018)4:11 ; doi:10.1038/s41523-

018-0063-9

Gene expression assays are commonly used to aid clinical decision-making in early stage estrogen receptor (ER)-positive, Her2-negative breast cancer because they provide complementary prognostic information to clinicopathologic features. Currently available assays include the 21 -gene Oncotype $D^{\circledR}{ }^{\circledR}$ Recurrence Score (Genomic Health, Inc., Redwood City, CA), ${ }^{1}$ the 70-gene MammaPrint ${ }^{\circledR}$ assay (Agendia Inc., USA), ${ }^{2}$ and others. ${ }^{3}$ The 21-gene and 70-gene assays also provide predictive information for chemotherapy benefit ${ }^{4,5}$ or lack thereof because of a very low recurrence risk with endocrine therapy alone, ${ }^{2,6,7}$ providing a foundation for their recommendation in practice guidelines. ${ }^{3,8}$ Evidence supporting the clinical utility of the 70-gene assay was provided by the MINDACT trial, which showed that tumors associated with high clinical risk and low genomic risk by the 70gene assay had a distant metastasis-free survival (DMFS) of $95 \%$ with endocrine therapy alone, which met the prespecified primary trial end point. ${ }^{2}$ Information provided by these assays result in a treatment change for up to $25 \%$, usually in the direction of sparing chemotherapy. ${ }^{9}$

Among the currently available assays, the 21-gene assay was one of the first to become commercially available and shown to be predictive of chemotherapy benefit, ${ }^{4,5}$ factors contributing to its widespread use. ${ }^{10}$ The 21 -gene assay provides a continuous recurrence score (RS) that allows more precise estimation of recurrence risk than a categorical classification, and also a categorical classification that includes not only "low-risk" (RS $<18$ ) and "high-risk" categories (RS $>30$ ), but also an "intermediate-risk" category (RS 18-30). Alternative RS cutpoints were proposed to define low risk $\left(\mathrm{RS}<11\right.$ ) and high risk $(\mathrm{RS}>25)^{11}$ to reflect an exclusively Her2-negative population, and reanalysis of the $\mathrm{B} 20$ validation study demonstrated a $2 \% 10$-year DMFS rate for those with a RS $<11$ treated with tamoxifen alone, and similar chemotherapy benefit using the lower RS cutpoint of 26 or higher (10-year DMFS rate $63 \%$ versus $88 \%$, hazard ratio [HR]: $0.29, p<$ $0.0001)^{11}$ as the original higher RS cutpoint of 31 or higher (10year DMFS $61 \%$ versus $88 \%$, HR: $0.26, p<0.001){ }^{4}$ The Trial Assigning Individualized Options for Treatment (TAILORx) was designed to prospectively determine whether adjuvant hormonal therapy is not inferior to chemohormonal therapy alone in patients with a "mid-range" RS of 11-25 (who had a 10-year DMFS rate of $5 \%$ with tamoxifen alone in the B20 trial), and to confirm the excellent outcomes for those with a RS $<11$ treated with hormone therapy alone. Although results from the low-risk arm have confirmed expectations, ${ }^{6}$ results from the "mid-range" group are still awaited. It is noteworthy that $67 \%$ of TAILORx participants had a RS of 11-25 compared with only $43 \%$ of B20 subjects, reflecting clinicians selectively ordering the test in clinical situations, where there is therapeutic equipoise. ${ }^{11}$ Identifying the optimal management strategy for this group remains a major unmet clinical need, for both node-negative and nodepositive disease.
In order to address this need, Tsai et al. described a prospective trial in which the impact of the 70-gene assay to guide treatment decisions was evaluated in 840 patients early stage ER-positive breast cancer with an "intermediate" RS of $18-30 .^{12}$ Chemotherapy was removed from the treatment recommendation in $29 \%$ with a "low-risk" signature (45\% of group), and added in $37 \%$ of those with a "high-risk" signature (55\% of group). Is this a reasonable approach to pursue in clinical practice outside the context of this trial?

The answer is no, for a number of reasons. First, although reports have indicated only a moderate degree of concordance in risk classification by 21 -gene assay and 70 -gene assay, ${ }_{1}^{13}$ there is no information about the analytic validity, or association with actual clinical outcomes, of their combined use. The report by Tsai et al. is no exception, since it focused on how adding the 70-gene assay impacts adjuvant chemotherapy use, not actual clinical benefit resulting from a treatment change (i.e., clinical utility). Second, it is fairly obvious that application of a binary test result ("low-risk" vs. "high-risk") to a group characterized as "intermediate-risk" by the 21-gene assay, however defined, will reclassify that group into two separate risk groups and influence clinical recommendations - an experiment with a predictable outcome. Third, this approach results in added assay costs without a clear return on investment, as the proportion of patients receiving chemotherapy actually increased by $8 \%$ with application of the 70-gene assay, and without much impact on patients with a RS of 26-30, few of whom were re-classified as "low-risk" by the 70-gene assay. Lastly and most importantly, the report by Tsai et al. provides no information regarding clinical risk as defined in MINDACT, which classified node-negative, ER-positive, Her2negative disease as clinically low risk if the primary tumor was $\leq 3 \mathrm{~cm}$ and associated with low histologic grade, $\leq 2 \mathrm{~cm}$ if intermediate grade, or $\leq 1 \mathrm{~cm}$ if high grade; ${ }^{2}$ given that $87 \%$ had node-negative disease, $76 \%$ had tumors $\leq 2 \mathrm{~cm}$, and $79 \%$ had lowintermediate grade tumors, it is likely that most had clinically lowrisk disease as defined in MINDACT. Among the 478 patients in MINDACT who had clinically low risk, genomically high-risk disease, there was no significant benefit from chemotherapy (5year DMFS $94 \%$ vs. $96 \%$, HR: $0.90, p=0.80$ ), although the trial was underpowered for this comparison.

Taken together, these considerations call into question the major conclusion of the authors that use the 70-gene assay in this setting "...provides clinically actionable information...", as there is little evidence that the actions taken would result in clinical benefit. Using any of the other currently available gene expression assays, which are also driven largely by genes reflecting ER signaling and proliferation, ${ }^{14}$ is not likely to be a fruitful approach when there is an "intermediate" RS, however defined. Other approaches that merit further evaluation include refining the 21gene assay by adding other highly prognostic genes, ${ }^{15,16}$ or using $\mathrm{RS}$ in combination with other assays that reflect other biologic processes. $^{17}$

Received: 11 November 2017 Revised: 31 March 2018 Accepted: 6 April 2018

Published online: 22 May 2018 


\section{ACKNOWLEDGEMENTS}

This study was supported in part by grants from the Department of Health and Human Services and the National Institutes of Health (5P30 CA 013330, 1U10CA180820, and 1UG1CA189859) and V Foundation (2017-007).

\section{ADDITIONAL INFORMATION}

Competing interests: J.A.S. holds equity interest in MetaStat, Inc.

Publisher's note: Springer Nature remains neutral with regard to jurisdictional claims in published maps and institutional affiliations.

Joseph A. Sparano iD ${ }^{1}$

${ }^{1}$ Montefiore Medical Center, Albert Einstein College of Medicine, Bronx, NY, USA

Correspondence: Joseph A. Sparano (jsparano@montefiore.org)

\section{REFERENCES}

1. Paik, S. et al. A multigene assay to predict recurrence of tamoxifen-treated, nodenegative breast cancer. N. Eng. J. Med. 351, 2817-2826 (2004).

2. Cardoso, F. et al. 70-Gene signature as an aid to treatment decisions in earlystage breast cancer. N. Eng. J. Med. 375, 717-729 (2016).

3. Krop, I. et al. Use of biomarkers to guide decisions on adjuvant systemic therapy for women with early-stage invasive breast cancer: American Society of Clinical Oncology Clinical Practice Guideline Focused Update. J. Clin. Oncol. 35, 2838-2847 (2017).

4. Paik, S. et al. Gene expression and benefit of chemotherapy in women with nodenegative, estrogen receptor-positive breast cancer. J. Clin. Oncol. 24, 3726-3734 (2006).

5. Albain, K. S. et al. Prognostic and predictive value of the 21-gene recurrence score assay in postmenopausal women with node-positive, oestrogen-receptorpositive breast cancer on chemotherapy: a retrospective analysis of a randomised trial. Lancet Oncol. 11, 55-65 (2010).

6. Sparano, J. A. et al. Prospective validation of a 21-gene expression assay in breast cancer. N. Engl. J. Med. 373, 2005-2014 (2015).

7. Drukker, C. A. et al. A prospective evaluation of a breast cancer prognosis signature in the observational RASTER study. Int. J. Cancer 133, 929-936 (2013).

8. Gradishar, W. J. et al. NCCN guidelines insights: breast cancer, version 1.2017. J. Natl Compr. Cancer Netw. 15, 433-451 (2017)
9. Sparano, J. A. \& Solin, L. J. Defining the clinical utility of gene expression assays in breast cancer: the intersection of science and art in clinical decision making. J. Clin. Oncol. 28, 1625-1627 (2010).

10. Petkov, V. I. et al. Breast-cancer-specific mortality in patients treated based on the 21-gene assay: a SEER population-based study. NPJ Breast Cancer 2, 16017 (2016).

11. Sparano, J. A. \& Paik, S. Development of the 21-gene assay and its application in clinical practice and clinical trials. J. Clin. Oncol. 26, 721-728 (2008).

12. Tsai, M. et al. Association of 70 -gene signature assay findings with physicians' treatment guidance for patients with early breast cancer classified as intermediate risk by the 21-gene assay. JAMA Oncol. e173470, https://doi.org/10.1001/ jamaoncol.2017.3470 (2017).

13. Bartlett, J. M. et al. Comparing breast cancer multiparameter tests in the OPTIMA prelim trial: no test is more equal than the others. J. Natl Cancer. Inst. 108, https:// doi.org/10.1093/jnci/djw050 (2016).

14. Wirapati, P. et al. Meta-analysis of gene expression profiles in breast cancer: toward a unified understanding of breast cancer subtyping and prognosis signatures. Breast Cancer Res. 10, R65 (2008).

15. Sparano, J. A. et al. Relationship between topoisomerase 2A RNA expression and recurrence after adjuvant chemotherapy for breast cancer. Clin. Cancer Res. 15, 7693-7700 (2009).

16. Sparano, J. A., Goldstein, L. J., Davidson, N. E., Sledge, G. W. Jr \& Gray, R. TOP2A RNA expression and recurrence in estrogen receptor-positive breast cancer. Breast Cancer Res. Treat. 134, 751-757 (2012).

17. Sparano J. A. et al. A metastasis biomarker (MetaSite Breast ${ }^{\mathrm{TM}}$ Score) is associated with distant recurrence in hormone receptor-positive, HER2-negative early stage breast cancer. NPJ Breast Cancer 3, https://doi.org/10.1038/S41523-017-0043-5 (2017).

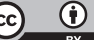

Open Access This article is licensed under a Creative Commons Attribution 4.0 International License, which permits use, sharing, adaptation, distribution and reproduction in any medium or format, as long as you give appropriate credit to the original author(s) and the source, provide a link to the Creative Commons license, and indicate if changes were made. The images or other third party material in this article are included in the article's Creative Commons license, unless indicated otherwise in a credit line to the material. If material is not included in the article's Creative Commons license and your intended use is not permitted by statutory regulation or exceeds the permitted use, you will need to obtain permission directly from the copyright holder. To view a copy of this license, visit http://creativecommons. org/licenses/by/4.0/.

(c) The Author(s) 2018 